SHORT TITLE: Climate change increases complementarity in pine/beech mixedwoods

This is the peer reviewed version of the following article: González de Andrés E., Seely B., Blanco J.A., Imbert J.B., Lo Y-H, Castillo F.J. Increased complementarity in water-limited environments in Scots pine and European beech mixtures under climate change. Ecohydrol. 2017;10:e1810, which has been published in final form at https://doi.org/10.1002/eco.1810. This article may be used for non-commercial purposes in accordance with Wiley Terms and Conditions for Self-Archiving.

\title{
Increased complementarity in water-limited environments in Scots pine and European beech mixtures under climate change
}

Ester González de Andrés ${ }^{1}$, Brad Seely ${ }^{2}$, Juan A. Blanco ${ }^{1, *}$, J. Bosco Imbert ${ }^{1}$, Yueh-Hsin Lo ${ }^{1}$, Federico J. Castillo ${ }^{1}$

${ }^{1}$ Dep. Ciencias del Medio Natural, Universidad Pública de Navarra, Campus de Arrosadía, Pamplona, Navarra, 31006, Spain.

${ }^{2}$ Dep. Forest Resource Management, University of British Columbia, 2424 Main Mall, Vancouver, British Columbia, V6T1Z4, Canada.

E-mails:

ester.gonzalez@unavarra.es

brad.seely@ubc.ca

juan.blanco@unavarra.es

bosco.imbert@unavarra.es

yuehhsin.lo@gmail.com

federico.castillo@unavarra.es

* Corresponding author: Juan A. Blanco

Tel: (+34) 948169859

Fax: (+34) 948169830

Manuscript submitted to the special issue "Forest Disturbance, Climate Change and Hydrology" 


\begin{abstract}
(250 words)
Management of mixedwoods is advocated as an effective adaptation strategy to increase ecosystem resiliency in the context of climate change. While mixedwoods have been shown to have greater resource use efficiency relative to pure stands, considerable uncertainty remains with respect to the underlying ecological processes. We explored species interactions in Scots pine / European beech mixedwoods with the process-based model FORECAST Climate. The model was calibrated for two contrasting forests in the southwestern Pyrenees (northern Spain): a wet Mediterranean site at 625 m.a.s.l. and a subalpine site at 1335 m.a.s.l. Predicted mixedwood yield was higher than that for beech stands but lower than pine stands. When simulating climate change, mixedwood yield was reduced at the Mediterranean site (-33\%) but increased at the subalpine site $(+11 \%)$. Interaction effects were enhanced as stands developed. Complementarity dominated the Mediterranean stand but neutral or net competition dominated the subalpine stand, which had higher stand density and water availability. Reduced water demand and consumption, increased canopy interception, and improved water-use efficiency in mixtures compared to beech stands suggest a release of beech intra-specific competition. Beech also facilitated pine growth through better litter quality, non-symbiotic nitrogen fixation and above- and belowground stratification, leading to higher foliar nitrogen content and deeper canopies in pines. In conclusion, mixtures may improve water availability and use efficiency for beech and light interception for pine, the main limiting factors for each species, respectively. Encouraging pine-beech mixtures could be an effective adaptation to climate change in drought-prone sites in the Mediterranean region.
\end{abstract}

Keywords (8): Species complementarity, mixedwoods, ecological modelling, Pinus sylvestris, Fagus sylvatica, interspecific competition, intraspecific competition, Pyrenees. 


\section{Introduction}

Climate is one of the main environmental factors determining forest ecosystems structure and function, as it affects key processes such as tree growth and mortality, nutrient cycling, and species interactions. Human-induced climate change is expected to result in escalating atmospheric and surface temperatures for the $21^{\text {st }}$ century with associated changes in precipitation regimes and expected increases in the frequency and severity of extreme drought events in many parts of the world (IPCC, 2013). It is anticipated that climate change will have both positive and negative impacts on forest growth depending on species characteristics and regional patterns. Expected positive impacts include increases in forest vigour and growth from improved water use efficiency associated with elevated atmospheric $\mathrm{CO}_{2}$ concentrations, and longer growing seasons in temperature-limited ecosystems (Körner, 2000; Huang et al., 2007). Expected negative impacts include growth reductions and mortality associated with increases in water and heat stress, and elevated mortality related to climate-driven changes in the dynamics of forest insects and pathogens (Allen et al., 2010).

The management of forests in a mixed condition (with two or more tree species) has been increasingly recognized as superior to monocultures with respect to the provision of a full range of ecosystem services (Loreau et al., 2001). Moreover, silviculture is gradually moving towards forest mixtures as an adaptation strategy designed to enhance ecosystem resiliency through the reduction of species-specific risks associated with global change (Jactel et al., 2009; Messier et al., 2013). The impacts of mixing species on stand-level productivity have been attributed to changes in nutrient and water availability, light-related interactions (light absorption and light use efficiency), and resilience to biotic or mechanical disturbances among others (Jactel et al., 2009; Richards et al., 2010; Forrester, 2014, 2015). Such interactions between species tend to be dynamic in nature, changing along spatial and temporal gradients in resource availability and climatic conditions (Forrester, 2014).

Inter-specific differences in physiology, phenology, or morphology can influence species and stand production (Forrester and Bauhus, 2016). These processes are often grouped into the phenomena of facilitation (i.e. one species improves the resource availability, climatic or biotic conditions of another species) or competitive reduction (i.e. inter-specific competition in the mixture is lower than intra-specific competition in pure stands). However, the inter-dependence among ecological processes in mixtures makes it extremely difficult to separate the effects of facilitation and competitive reduction (Kelty and Cameron, 1995; Loreau and Hector, 2001; Forrester, 2014). Alternatively, facilitation and competitive reduction have been described collectively as complementarity (Loreau and Hector, 2001). Recent experimental studies (Forrester, 2015), reviews (Forrester, 2014; Forrester and Bauhus, 2016) and 
modelling approaches (Wu et al. 2015; Forrester and Tang, 2016) have analyzed such complementarity concept in forest ecosystems.

In Europe, the light-demanding Scots pine (Pinus sylvestris L.) and the shade-tolerant European beech (Fagus sylvatica L.) are the most widely distributed conifer and broadleaf species, and their distributions overlap over a large area of the continent (Fig.1). Although mixtures of beech and pine have been observed to provide an overall increase in yield of $12 \%$ in comparison with monospecific stands (Pretzsch et al., 2015), it is unclear if this relationship will be consistent under different stand conditions (e.g. ages, densities and edaphic conditions) and under changing climate conditions. As the climate in continental Europe shifts towards warmer and drier summers in the South, and warmer and wetter summers in the North (IPCC, 2013), there is a potential for the range of Scots pine to expand northwards and upwards in elevation. In contrast, beech is expected to migrate towards higher elevations but to decline in lower and mid altitudes, where it could be replaced by pine or other species (Peñuelas and Boada, 2003). The Iberian Peninsula represents the southern and western limits of the range of both Scots pine and European beech (Fig. 1). Accordingly, this region is likely to be highly sensitive to climate change. Hence, an analysis of the potential impacts of climate changes on these rear-edge forests will provide valuable insight towards understanding long-term impacts of warmer and/or drier conditions throughout the broader range of these species.

Given the lack of long-term field studies in mixed forest and the uncertainty in changing climatic conditions, forest growth models provide one of the best available methods to examine long-term patterns of growth and development in mixedwoods and their potential behaviour under alternative climate change scenarios. Hybrid models combining ecological processes and empirical data can be effective tools for projecting development under untested growing conditions, novel silvicultural regimes, and alternative species combinations and proportions (Blanco et al., 2015).

The objectives of this study are: 1) to explore underlying causes of complementarity and competition in mixed pine and beech forests in the southwestern Pyrenees, and 2) to evaluate the potential impacts of climate change on forest nutrient and water dynamics, and ultimately on tree growth and complementarity in two different study sites. Complementarity was considered to occur when the mixed stand growth exceeded from the weighted growth average of both monospecific stands (Loreau and Hector, 2001). We hypothesize that pine and beech growing in intimate mixtures will experience improved water and nutrient availability, capture and/or use efficiency relative to pure stands, particularly under warmer and drier conditions associated with climate change. Likewise, we hypothesize that Iberian mixed pine-beech 
forests will be more productive than monospecific forests and that the complementarity effects will vary over time.

To test these hypotheses we have employed the process-based, ecosystem-level model FORECAST Climate (Seely et al., 2015) to simulate the development of forest ecosystems under a reference climate and different climate change scenarios derived from six global circulation models (GCMs) and two representative concentration pathways (RCPs). FORECAST Climate is able to simulate the movement of water through various forest layers including explicit representations of the balance between inputs from precipitation and seepage, and outputs by canopy interception, evapotranspiration, plant uptake, percolation and runoff. The model has been tested and applied for a wide variety of forest ecosystems (Dordel et al., 2011; Blanco et al., 2015; Lo et al., 2015; Seely et al. 2015, and references therein).

\section{Material and methods}

\subsection{Study sites}

The study area is located in the southwestern Pyrenees in the province of Navarre (northern Spain; Fig.1). Using data from experimental plots monitored since 1999 (pine stands) and 2013 (beech stands), FORECAST Climate was calibrated to simulate two contrasting pine-beech mixedwoods: a Mediterranean low-elevation site (Aspurz), and a subalpine high-elevation site (Garde) (Fig.1, Table 1). In this region, management plans have favored the presence of monospecific stands of Scots pine, which is a more marketable species. However, more recently mixed stands have been encouraged by facilitating beech regeneration and growth under maturing pine canopies (Condés et al., 2013).

Historical climate data were obtained from the nearest weather stations to each study site. Due to the elevation difference between the subalpine experimental plots and the closest weather station (about 600 $\mathrm{m}$ ), climate data were adjusted using the MounTain microCLIMate simulation model (MT-CLIM; Running et al. 1987). Maximum and minimum temperature lapse rates and precipitation isohyets needed for the extrapolation were calculated from regional climate data. Missing data were calculated by interpolating values from nearby weather stations. For the period 1975-2004 mean growing season (MayOctober) temperature was $16.8^{\circ} \mathrm{C}$ and $14.5^{\circ} \mathrm{C}$ and precipitation amount was $402 \mathrm{~mm}$ and $743 \mathrm{~mm}$ for the Mediterranean and subalpine sites, respectively (Fig. 2). Summer droughts are frequent in the Mediterranean site. Soil characteristics are summarized in Table 2. 


\subsection{Model description}

FORECAST Climate is an ecosystem-level, non-spatial, stand-scale, forest growth simulator. It includes the basic FORest and Environmental Change ASsessment Tool (FORECAST; Kimmins et al., 1999) and the new hydrological module based on the Forest Water Dynamics model (ForWaDy; Seely et al., 1997). As the model has been recently described in detail (Seely et al. 2015), only a basic description is provided here.

\subsubsection{The forest growth model FORECAST}

The FORECAST model was designed to accommodate a wide variety of harvesting and silvicultural systems in order to compare and contrast their effect upon forest productivity, stand dynamics and a series of biophysical indicators of non-timber values. Tree growth is limited by available light and nutrients (Fig. S1A) and the model uses a mass balance approach to simulate nutrient cycling Rates of key ecosystem processes are calculated at an annual time step from a combination of historical bioassay data (biomass accumulation in component pools, stand density, etc.) and measures of certain ecosystem variables (e.g., decomposition rates, photosynthetic saturation curves) by relating "biologically active" biomass components (foliage and small roots) with calculations of nutrient uptake, the capture of light energy, and net primary production. In this way the model generates a set of growth properties for each tree and plant species which includes, among others, 1) photosynthetic efficiency per unit of foliage biomass based on relationships between foliage biomass, simulated self-shading, and net primary productivity after accounting for litterfall and mortality, 2) nutrient uptake requirements based on rates of biomass accumulation and nutrient concentrations in different biomass components on different site qualities, and 3) light-related measures of tree and branch mortality derived from stand density input data in combination with simulated light profiles. The model simulates the dynamics of all major forest carbon stocks (aboveground biomass, belowground biomass, litter, dead wood and soil organic carbon). It complies with the carbon estimation methods outlined by the IPCC (Penman, 2003). See the Supplementary Material and Kimmins et al. (1999) for further details.

\subsubsection{The forest hydrology model ForWaDy}

ForWaDy (Seely et al., 1997) is a two-dimensional forest hydrology model that simulates the hydrological dynamics of a forest stand on a daily time step under a given set of climatic and vegetation conditions. It has been validated against field-measured soil moisture data (Titus et al., 2006; Dordel et al., 2011). In the FORECAST Climate model, ForWaDy is dynamically linked to FORECAST to facilitate an explicit representation of water availability and competition for limited water resources on 
tree growth and other ecosystem-level processes. Reconciliation between the different temporal resolutions of each model is made through the usage of annual indices (calculated from the daily ForWaDy output) as input to FORECAST (Seely et al., 2015). Conversely, FORECAST provides annually updated input to ForWaDy in the form of species-specific estimates of leaf area index, canopy radiation interception, and soil occupation by fine root biomass. It also provides information regarding the formation of soil organic matter and its distribution within specific soil layers.

ForWaDy calculates potential evapotranspiration (PET) using net shortwave solar radiation interception and an empirically based energy budget approach. PET is estimated separately for the canopy, understory, and forest floor. Hydrological dynamics in the forest floor and rooting zone are simulated using a multilayered approach (Fig. S1B). Water storage and vertical movement through each soil layer are regulated by its physical properties that dictate moisture holding capacity, permanent wilting point moisture content, and infiltration rate. Water stress is calculated daily for each species separately as the relative difference between potential energy-limited transpiration demand and actual transpiration. This is represented by a dimensionless transpiration deficit index (TDI; Eq. 1):

$$
T D I=\frac{\text { CanT }_{\text {Demand } i, d}-\text { CanT }_{\text {Actual } i, d}}{\text { CanT }_{\text {Demand } i, d}}
$$

where, $\operatorname{CanT}_{\text {Demand, i,d }}$ is the energy-limited transpiration for species $i$ on a day $d$, depending on leaf area index (LAI), intercepted short-wave radiation, canopy albedo, and canopy resistance; and CanT $\mathrm{Actual}_{\mathrm{i}, \mathrm{d}}$ is the soil-limited transpiration, calculated as a function of $\mathrm{CanT}_{\text {Demand, i,d }}$, root occupancy, and available soil moisture. A higher TDI value indicates greater moisture stress. A detailed description of the ForWaDy model is presented in Seely et al. $(1997,2015)$.

\subsubsection{Climate impacts on productivity, decomposition, and mortality}

The impact of temperature and water availability on plant growth is represented in FORECAST Climate with species-specific curvilinear response functions (Fig. S2). A daily growth response index is calculated as the product of the temperature and moisture effects and summed over the year to generate an annual growth response index. A similar approach is utilized to represent the impact of temperature and moisture content on decomposition rates. Reference values for the annual climate response indices are determined from a series of climate calibration runs in which historical climate data from a 20 to 30 year reference period are used as model inputs. During climate change simulations, current-year climate response indices are compared against mean reference values to determine the degree to which species-specific base growth rates and litter-type specific base decomposition rates should be adjusted to account for climate effects. FORECAST Climate also includes a representation drought mortality associated with prolonged 
periods of water stress (Allen et al., 2010). Water stress mortality is simulated as a function of two-year running average water stress based upon TDI (Fig. S3). Further explanations are provided in the Supplementary Material.

\subsection{Model calibration and simulation}

\subsubsection{FORECAST Climate calibration}

Calibration data from Scots pine and European beech sites used to parameterize the base FORECAST model are provided in the Supplementary Material (Tables S2 and S3). In addition, the forest hydrology sub-model ForWaDy requires data describing characteristics of the soil profile from each site. These data were obtained by digging soil pits in each site (Table 2). Parameters regulating hydrological processes such as transpiration rates, soil water uptake and water stress development for simulated tree and plant species are provided in Table 3. A detailed summary of empirical and literature sources for model calibration data and input parameters is provided in the Supplementary Material.

\subsubsection{Simulating climate change impacts on forest ecosystems}

Performance of monospecific and mixed pine and beech forests in the southwestern Pyrenees under different climate change scenarios was assessed. Natural regeneration of both species was simulated as occurring at year 1 of simulation, with no further regeneration events. Seedling regeneration densities in the monospecific stands were based on regional growth and yield tables for these species (Madrigal et al., 1992; Puertas, 2003). Condés et al. (2013) observed that stand density in Navarre's pine-beech mixedwoods is usually divided between pine and beech at 50\%-50\% species proportions. Similar average proportions were reported by Preztsch et al. (2015) for the whole natural range of both species along Europe. Therefore, seedling density for each species in mixed stands was set up as the $50 \%$ of the density of each species in monospecific stands. This procedure allowed comparisons of species performance when growing alone and together with the other species. To obtain growth predictions meaningful for forests already established, climate change impacts were simulated starting on year 51, which was the average tree age in the experimental plots used to obtain empirical calibration values (see Table 1).

Three climate change scenarios were simulated: historical, moderate and severe. In the case of the historical scenario, atmospheric $\mathrm{CO}_{2}$ concentration were held constant at 2004 levels (377 ppm) to approximate a no-change baseline. Historical climate data from the period of 1975-2004 (see section 2.1) were cycled five times to generate 150 years of daily data to represent the historical (no-change) climate scenario. The moderate and severe climate change scenarios were derived from six GCMs included as part of the Intergovernmental Panel on Climate Change AR5 analysis (IPCC 2013; Table S4). Two $\mathrm{CO}_{2}$ 
emissions pathways that generate radiative forcing of $4.5 \mathrm{Wm}^{-2}(\mathrm{RCP} 4.5)$ and $8.5 \mathrm{Wm}^{-2}$ (RCP 8.5) were selected, corresponding to moderate and severe scenarios, respectively (Meinshausen et al., 2011; Fig. S4). GCMs were downscaled using the Statistical Downscaling Model (SDSM; Wilby and Dawson, 2013). The projections of five weather stations near the study sites (Fig. 1) were averaged to generate climate change scenarios. The resulting data sets spanned 100 years (2015-2114). Under these scenarios, mean growing season temperature in the Mediterranean and the subalpine study sites were predicted to rise from about $16.8^{\circ} \mathrm{C}$ and $14.2^{\circ} \mathrm{C}$ in 2015 to $19.7 \pm 0.2^{\circ} \mathrm{C}$ and $15.2 \pm 0.2{ }^{\circ} \mathrm{C}\left(\mathrm{RCP} 4.5\right.$ ) or $24.2 \pm 0.4{ }^{\circ} \mathrm{C}$ and $19.6 \pm 0.4{ }^{\circ} \mathrm{C}(\mathrm{RCP} 8.5)$ by the beginning of the $22^{\text {th }}$ century, respectively. However, there is a great variability among the precipitation predictions among models, and no common trends can be derived. Detailed descriptions of the modeled climate change scenarios are provided in the Supplementary Material (Figs. S5A and S5B).

\subsection{Evaluation of stand-level performance through complementarity}

Complementarity, which appears when the interactions between species have a net positive influence due to resource partitioning or facilitation (Loreau and Hector, 2001), was assessed at species and stand levels with Eq. 2 and Eq. 3, respectively, at each time step (year) for each simulation conducted.

$$
\begin{aligned}
& \text { Species complementarity }_{i, j}(\%)=100 \times\left(\frac{Y_{\text {mixed } i, j}}{Y_{\text {mono } i, j} \times S p_{i, j}}-1\right) \\
& \text { Mixed stand complementarity } \\
& j(\%)=100 \times\left(\frac{Y_{\text {mixed } P s, j}+Y_{\text {mixed } F s, j}}{Y_{\text {mono } P s, j} \times S p_{P s, j}+Y_{\text {mono } F s, j} \times S p_{F s, j}}-1\right)
\end{aligned}
$$

where $Y_{\text {mixed } i, j}$ is the stemwood yield of species $i$ (Scots pine or European beech) in the mixed stand at year $j$ and $Y_{\text {mono } i, j}$ is the stemwood yield of species $i$ at year $j$ growing in a monoculture. $S p$ is the species $i$ proportion, calculated as the species density at year $j$ (number of stems per hectare) in mixtures divided by the species density in a monospecific stand of the same species $i$ simulated under the same climate scenario for the same year $j$. The $P s$ and $F s$ subscripts indicate pine and beech, respectively. Negative values of complementarity were interpreted as competition. Both equations are based on the selection and complementarity effects calculations proposed by Loreau and Hector (2001) and adapted by Forrester (2014). Alternative approaches to quantifying complementarity are also available (Fox, 2005; Wu et al., 2015) but are not used in this study.

Two additional metrics of species performance were assessed including annual water use-efficiency (WUE) and nitrogen use-efficiency (NUE). WUE was determined as the ratio of net primary production (NPP, which was estimated as the sum of biomass increment, litterfall and mortality), to canopy transpiration (Sinclair et al., 1984). NUE was calculated as the ratio between NPP and the net uptake of 
nitrogen by each species (Lodhiyal et al., 1995). The above metrics were used to compare performance of: 1) monospecific and mixed stands under the historical climate scenario, and 2) mixtures with both historical and climate change scenarios.

\section{Results}

\subsection{Species interaction in historical climate simulations}

In the case of the historical climate simulation, FORECAST Climate predicted a total yield in pine and beech mixtures of about $870 \mathrm{Mg} \mathrm{ha}^{-1}$ in the Mediterranean site and $550 \mathrm{Mg} \mathrm{ha}^{-1}$ in the subalpine site. In both sites, mixtures had higher yields than monospecific beech stands but lower than pure pine stands. An increasing temporal trend in stand-level complementarity as stands developed was found for the Mediterranean site. However, interaction effects between species in the subalpine site were weaker, starting with initial net competitive effects (negative complementarity) evolving over time towards facilitation (slightly positive complementarity, Fig. 3A). Annual stand productivity was greater in mature mixtures (over 100 years) at both sites (Fig. 4A). Yield complementarity and productivity patterns may be explained by improved nutrient status in mixtures compared to monospecific pine stands (Fig. 4B), lower water demand for transpiration (Fig. 4C), and higher NUE (Fig. 4D) for mixtures than for beech stands. In fact, nitrogen-leaching losses decreased $40 \%$ in the Mediterranean site and $75 \%$ in the subalpine site for mixtures relative to monospecific stands. Canopy precipitation interception of mixtures was close to that of monospecific pine stands while it was always lower than beech stands (Table 4). There were no differences in maximum rooting depth between the stands in either site. However, combined tree root occupancy of all soil layers was higher in mixtures than in monospecific stands.

Species-specific results show that complementarity was also greater in the Mediterranean site for both species (Fig. 3B; Table S5). Foliar nitrogen content per tree in pines was higher in mixtures than in monospecific stands (Fig. 5A). In mixed stands, crown length was 1.0 and $3.3 \mathrm{~m}$ greater than in mature pure pine stands at the Mediterranean and subalpine elevation sites, respectively. Although average pine transpiration per tree was higher in mixtures due to increased productivity (Fig. 5B), no changes in WUE were predicted (Fig. 5D). In contrast, foliar nitrogen content per tree in beech was lower in mixed stands due to competition from pine (Fig. 6A). Therefore, simulated positive mixing effects on beech in the Mediterranean site were not light-related but associated with improved resource use efficiency (Fig. 6D).

\subsection{Impacts of climate change on ecological processes in mixed stands}

Stand biomass accumulation under climate change (calculated as the average of moderate and severe climate change scenarios relative to the historical scenario) was significantly reduced in mixed stands in 
the Mediterranean site (-33\%) and moderately increased in the subalpine site $(+11 \%)$. This is consistent with the trends predicted for stand productivity, which decreased in the Mediterranean site and remained steady (or rising for the severe climate change scenario) in the subalpine site (Fig. 7A). Climate change had only minor impacts on stand complementarity, with the notable exception of the 150 -year period at the subalpine site under severe climate change. At this site and time, complementarity increased substantially (Fig. 3A) following a period of drought-induced beech mortality. Predicted warmer temperatures led to accelerated decomposition of litter at both sites (Fig. 7D), but only at the subalpine site the net nitrogen balance increased (Fig. 7B). Stand-level canopy transpiration rates showed a minor increase in the climate change scenarios relative to the historical scenario at both sites (Fig. 7C). In contrast, warmer conditions and increased nitrogen mineralization at the subalpine site led to increased growth rates for both species. Moisture availability was not a limiting factor on growth in this site. Simulation results for the growth response index (GRI), TDI and drought-related mortality at the specieslevel are shown for mixed stands in Fig. S6.

Complementarity for beech stemwood biomass increased as temperature and rainfall variability also increased in the Mediterranean site (Fig. 3B). Relative to monospecific stands, beech growing in mixtures under climate change showed increases in foliar nitrogen content and WUE, and concurrent reductions in water stress (Fig. 6). In contrast, complementarity for pine did not vary considerably in the climate change scenarios relative to the historical climate simulation. While the effects of mixing on foliage nitrogen content declined with climate change, WUE was greater for pines in mixtures relative to monocultures (Fig. 5). The relatively minor effects of mixing on light-, nutrient- and water-related processes in the subalpine site are consistent with limited complementarity levels also estimated for this site.

\section{Discussion}

The prospect of climate change for the future survival and sustainability of beech has become of greater concern due to its high sensitivity to drought (Geßler et al., 2007). Pure pine stands also appear to be increasingly vulnerable to climate change, primarily because of the increased risk of insect outbreaks and fungal disease in such stands (Allen et al., 2010). Inter-specific differences in physiological and morphological traits provide advantage for pine-beech mixtures in terms of resource efficiency and overall resilience relative to monospecific stands (Pretzsch et al., 2015), particularly in the context of climate change. Although our modelling approach has some limitations (see below), it also has advantages that facilitate the analysis of potential impacts of climate change on key ecological processes, including nutrient and water availability, and efficiency of their use as well as the effects of different 
levels of species mixing, including proportions and total stand density (Río et al., 2014a; Blanco et al., 2015).

Differences between species growth rates were too large and mixing positive effects not big enough for stand biomass in mixtures to be greater than biomass in both monospecific stands. Nevertheless, complementarity effects (positive interaction) were predicted at stand- and species-levels for both sites. Facilitation, competitive reduction (considered jointly as complementarity) and competition in mixedwoods occur simultaneously. Changes in the importance of each factor have an influence on NPP. When species interactions improve the availability, uptake, or use efficiency of a resource that is becoming more limiting along the spatial or temporal gradient, complementarity also tends to increase along that gradient (Binkley et al., 2004; Forrester, 2014). The stress gradient hypothesis (Bertness and Callaway, 1994) has been recently considered as a special case that fits within the general 'complementarity - competition' framework (Forrester and Bauhus, 2016). However, there are some differences between the 'complementarity - competition' framework and the stress gradient hypothesis. One difference is the nature of agronomic studies traditionally used to test the stress gradient hypothesis, whereas the 'complementarity - competition' framework has been applied more often to forest ecosystems. Another difference is the consideration of facilitation and competitive reduction instead of just facilitation, or the difficulty to distinguish both processes occurring simultaneously in forests (Forrester and Bauhus, 2016). In spite of these difficulties, several recent studies have successfully applied the stress gradient hypothesis to forest ecosystems in permanent environmental gradients or under episodic severe conditions (e.g. Pretzsch et al., 2012; Forrester, 2014; Río et al., 2014a).

\subsection{Understanding pine-beech interactions in the southwestern Pyrenees}

Beech is known to have high drought sensitivity. Intensive summer droughts can significantly limit its growth and competitive ability (Geßler et al., 2007). Thus, greater complementarity effects on this species at the Mediterranean site compared with the subalpine site are consistent with the "complementarity competition' framework, as long as we consider water to exert a higher limitation than nutrients on beech growth. Supporting this assumption, Condés and Río (2015) found that water resources are of greater importance for beech than for pine in this region, increasing the effect of competition for nutrients and light with higher precipitation in the same region. Such is the case of the subalpine site, where higher density might also promote competitive interactions.

Stress release of beech when mixed with different species has been reported in several studies (Pretzsch $e t$ al., 2012; Condés et al., 2013; Río et al., 2014a, b). Similarly, our results suggest that given the low selftolerance of beech, complementarity may arise from processes that release intra-specific competition for 
water in mixtures. Transpiration is one of the key processes that influences water availability (Forrester, 2015). Thus, the improvement in WUE in mixed stands suggests that beech may better tolerate drier conditions if grown in mixed stands relative to pure stands. Such result is in line with observations field observations at the Mediterranean site by Primicia et al. (2013), who reported beech radial growth during the water stress season when mixed with pine.

In addition to transpiration, there are several simultaneous processes that could influence water availability and drought stress in mixtures (Forrester, 2015). In FORECAST Climate, transpiration demand decreases as crown evaporation increases and energy is consumed in the process of crown evaporation (Seely et al., 2015). Thus, the simulated increase in the proportion of precipitation intercepted by the canopy of mixed stands compared to beech monospecific stands may partly explain the increase in WUE. The increase in interception rates in mixed stands is likely caused by the combination of: 1) higher LAI in coniferous forests than in broadleaves, 2) the contrasting canopy architecture of the two species that combined produce a more complete use of the canopy space than each species by separate, and 3) the winter/early spring season when beech is defoliated but rainfall is important, which can therefore be intercepted by pine in mixed stands but not in pure beech woods (Fig. 2). In addition, belowground competition release could also improve water supply for beech in mixtures.

Water did not exert important limitation for pine growth, which seemed to be more dependent on light availability. Contrary to beech, pine growth and transpiration could have increased in response to processes that improve light and nutrient availability or uptake (Forrester, 2015). Such mechanisms have been proposed to occur in the presence of beech for this species mixture in this region (Río et al., 2014b; Condés and Río, 2015). The estimated spatial gradient in complementarity between our sites (which increased as nutrient supply improved) is also consistent with the 'complementarity - competition' framework, when light is considered the growth limiting resource for pine (Blanco et al., 2008; Forrester, 2014; Forrester and Bauhus, 2016).

Beech presence reduced aboveground intra-specific competition and improved nutrient supply for pine. Improvements in nutrient availability for pine in mixtures were more pronounced in the Mediterranean site and largely related to input from beech leaf litter. Compared to pine litter, beech litter has higher nutrient content, lower $\mathrm{C} / \mathrm{N}$ ratio and less recalcitrant compounds, resulting in higher activity of soil microfauna and therefore higher litter decomposition rate, reduced soil acidity and a richer humus type (Kelty and Cameron, 1995; Pretzsch et al., 2015). Non-symbiotic nitrogen fixation associated with beech litter also increased the available $\mathrm{N}$ content in mixed sites relative to pure pine sites. The resulting deeper canopies improved pine light interception in mixtures. In the subalpine site, nutrient availability is more 
limiting than in the Mediterranean site (Blanco et al., 2009, 2011) and, therefore, light-related complementarity was of lesser intensity. Competition for nutrients was also probably encouraged by the high tree density predicted for the subalpine site, in accordance to data reported from similar sites in this region (Condés et al., 2013).

Inter-specific differences in resource requirements and uptake abilities often result in niche differentiation and resource-use complementarity (Richards et al., 2010). The hypothesis of more complete belowground exploitation (Río et al., 2014b; Pretzsch et al., 2015) was supported by our simulations through higher combined root occupancy in mixtures, which led to reduced nitrogen leaching losses and improved NUE at the stand level. A more efficient use of crown space due to contrasting light compensation points and light-use efficiencies (Preztsch et al., 2015), phenological differences (Schwendenmann et al., 2015) and contrasting patterns of stomata closure under drought conditions between species (Forrester, 2015) have also been proposed as causes of complementarity in mixtures.

Recent studies based in the same region (Condés et al., 2013; Río et al., 2014b; Condés and Río, 2015) similarly found water and light to be the primary limiting resource factors for beech and pine performance, respectively. However, our results illustrate the importance of also accounting for species interactions with respect to the dynamics of nutrient availability and uptake. This is particularly important for predicting future growth and ecosystem resiliency trends under different silviculture systems and climate scenarios.

\subsection{Mixed stands projections under climate change}

The temporal patterns of variation in complementarity observed in this analysis highlight the importance of using a long-term approach when evaluating tree interactions under different stress gradients. This variation is likely derived from temporal changes in climatic conditions or disturbances and modification of availability of light and soil resources by stand development (Forrester, 2014). Our results point to the enhancement of interaction effects as stands develop over time. In the Mediterranean site, increasing stand complementarity was predicted for both species in mixtures. In the subalpine site, increasing complementarity and competition effects were predicted for pine and beech respectively. The projected trend of rising temperatures and increasing frequency of drought events (IPCC, 2013) in southwestern Europe suggest that beech will increasingly benefit from associations in mixtures, particularly in areas with Mediterranean climates where it is expected to suffer growth reductions related to declining soil moisture and reduced nitrogen supply (Geßler et al., 2007). Messier et al. (2013) observed similar benefits for beech growing in mixtures in terms of increased forest resilience in the context of climate change. 
Although pine is better adapted to dry conditions than beech and the main inter-specific interactions were nutrient- and light-related, the climate change simulations conducted here suggest that pine will also have better WUE when grown in a mixedwood condition. Regardless, water stress at the species-level was notably increased under climate change, because of the increased frequency of drought events, leading to higher drought-related mortality rates in the Mediterranean site. In any case, pine would also likely obtain greater additional benefits in mixtures from the mitigation of the susceptibility to secondary stress made by insects, fungi or windthrow damage caused by drought (Allen et al., 2010; Pretzsch et al., 2015). All our results together point to the advantage of mixtures for both species at stand-level to face warmer environments with more frequent drought events.

\subsection{Model advantages and limitations}

All models have strengths and weaknesses that should be taken into consideration when evaluating model results. One of the strengths of the FORECAST Climate as tool for examining species interactions in mixed stands is that it does not use competition indices as proxies for species interactions. Rather, it includes explicit representations of above and belowground competition for available resources including nutrients, light and water, therefore allowing for an examination of shifts in inter-specific interactions along spatio-temporal environmental gradients (Río et al., 2014a). While such features enhance the capability of simulating species interactions (Blanco et al., 2015; Pretzsch et al., 2015), they also come with the cost of increased calibration data.

Some of the limitations of FORECAST Climate with respect to its application in mixed species stands include the following. There is neither representation of mycorrhizal relationships nor simulation of hydraulic redistribution in the model. Both of these can be important factors regulating ecosystem function in mixedwood forests (Neumann and Cardon, 2012; Simard et al., 2012). In addition, droughtrelated mortality is empirically estimated based on monospecific stands, so the ability of the model to predict inter-specific interactions could be limited. Forrester (2015) showed that in mixtures not every tree of a given species present complementarity effects but only some of them grow faster than trees in monospecific stands and other trees grow at similar rates, and stand-level patterns will reflect the mean tree-level response. Thus, stand-level predictions could ignore potentially important individual tree responses. Additionally, the way in which density and species proportions are estimated could influence the calculation of complementarity. To address this issue, a species proportion definition that considers the different potential densities between species was chosen as it was referred to density in monospecific stands. This might provide more reliable estimation of mixing effects when there are differences in species potential densities (Sterba et al., 2014). A further limitation in our modelling approach could be 
attributed to the fact that the only nutrient considered was nitrogen. This assumption was based on previous research reporting that nitrogen is the main limiting nutrient at both sites (Blanco et al., 2008; 2009; 2011). However, recent findings suggest that phosphorous could also become limiting uner some conditions at least in the Mediterranean site for pine growth (Primicia et al., 2014). Hence, further work is needed at conceptual, modelling, and empirical levels to include multi-nutrient limitations and interactions with other factors in the context of the 'complementarity - competition' theoretical framework.

In spite of the aforementioned limitations, FORECAST Climate (and its predecessor FORECAST) have been successfully applied to a wide variety of situations (see Blanco et al., 2015, Lo et al., 2015; Seely et $a l ., 2015$ and references therein), including studies on complementarity and facilitation in tropical mixed plantations (Wu et al., 2015; Wei et al., 2014). This model has also been highlighted as one of the four more promising ecological models for its application in mixed forests, in a recent review encompassing 202 ecological models (Blanco et al., 2015). Such facts provide confidence in its suitability to simulate complex forest ecosystems.

\section{Conclusions}

In this study we provide insight towards a better understanding of inter-specific interactions in pine/beech mixedwoods growing close to their range limits. The results are also relevant across Europe as similar climate conditions may develop further north in more central distribution areas with climate change (Hampe and Petit, 2005). The study provides support for increasing the establishment pine-beech mixedwoods as an adaptation strategy to climate change in drought-prone sites. Our results suggest that the expected beneficial effect would be weaker high elevation sites where water availability is not a key factor limiting growth. Complementarity of beech increased as water availability (major limitation for this species) declined. In the case of pine, interactions in mixtures were light-related, and complementarity was higher as nutrient supply improved and competition for below-ground resources decreased. Thus, climate change was predicted to have a relatively smaller impact on pine grown in mixtures compared to beech. Our results are consistent with the 'complementarity - competition' framework as long as the limiting resources considered are water for beech and light for pine.

\section{Acknowledgements}

The authors wish to thank Dr. F.J. Arricibita for his assistance in the soil field sampling and chemical analysis, as well as all the previous graduate and undergraduate students working at UPNA's Ecology and Environment Group who had made possible to gather the 16-year long databases used for model calibration. Ester González de Andrés was funded through a Spanish Predoctoral Research Grant (ref. 
BES-2013-066705) and a mobility aid (ref. EEBB-I-15-09220). Funding for this research has been provided by the Spanish Ministry of Economy and Competitiveness (project AGL2012-33465), which also funded Yueh-Hsin Lo. Juan A. Blanco was funded through a Ramón y Cajal contract (ref. RYC2011-08082) and a Marie Curie Action (ref CIG-2012-326718-ECOPYREN3).

\section{References}

Allen CD, Macalady AK, Chenchouni H, Bachelet D, McDowell N, Vennetier M, Kitzberger T, Rigling A, Breshears DD, Hogg EH, Gonzalez P, Fensham R, Zhang Z, Castro J, Demidova N, Lim JH Allard G, Running SW, Semerci A, Cobb N. 2010. A global overview of drought and heat-induced tree mortality reveals emerging climate change risks for forests. Forest Ecology and Management 259: 660-684. DOI: doi:10.1016/j.foreco.2009.09.001.

Bertness MD, Callaway RM. 1994. Positive interactions in communities. Trends in Ecology and Evolution 9: 191-193. DOI: 10.1016/0169-5347(94)90088-4.

Binkley D, Stape JL, Ryan MG. 2004. Thinking about efficiency of resource use in forests. Forest Ecology and Management 193: 5-16. DOI: 10.1016/j.foreco.2004.01.019.

Blanco JA, Imbert JB, Castillo FJ. 2008. Nutrient return via litterfall in two contrasting Pinus sylvestris forests in the Pyrenees under different thinning intensities. Forest Ecology and Management 256: 1840-1852. DOI: 10.1016/j.foreco.2008.07.011.

Blanco JA, Imbert JB, Castillo FJ. 2009. Thinning affects nutrient resorption and nutrient-use efficiency in two Pinus sylvestris stands in the Pyrenees. Ecological Applications 19:682-698. DOI: 10.1890/1051-0761-19.3.682.

Blanco JA, Imbert JB, Castillo FJ. 2011. Thinning affects Pinus sylvestris needle decomposition rates and chemistry differently depending on site conditions. Biogeochemistry 106:397-414. DOI: 10.1007/s10533-010-9518-2.

Blanco JA, González de Andrés E, San Emeterio L, Lo YH. 2015. Modelling mixed forest stands: methodological challenges and approaches. In: Lek S., Park Y.S., Baehr C., Jorgensen S.E. (Eds.) Advanced Modelling Techniques Studying Global Changes in Environmental Sciences. Elsevier: Amsterdam, the Netherlands. Pp. 186-223. ISBN: 978-0-444-63-536-5.

Condés S, Río M, Sterba H. 2013. Mixing effect on volume growth of Fagus sylvatica and Pinus sylvestris is modulated by stand density. Forest Ecology and Management 292: 86-95. DOI: 10.1016/j.foreco.2012.12.013.

Condés S, Río M. 2015. Climate modifies tree interactions in terms of basal area growth and mortality in monospecific and mixed Fagus sylvatica and Pinus sylvestris forests. European Journal of Forest Research 134: 1095-1108. DOI: 10.1007/s10342-015-0912-0. 
Dordel J, Seely B, Simard S. 2011. Relationships between simulated water stress and mortality and growth rates in underplanted Toona ciliata Roem in subtropical Argentinean plantations. Ecological Modelling 222: 3226-3235. DOI: 10.1016/j.ecolmodel.2011.05.027.

Forrester DI. 2014. The spatial and temporal dynamics of species interactions in mixed-species forests: From pattern to process. Forest Ecology and Management 312: 282-292. DOI: 10.1016/j.foreco.2013.10.003.

Forrester DI. 2015. Transpiration and water-use efficiency in mixed-species forests versus monocultures: effects of tree size, stand density and season. Tree Physiology 35: 289-304. DOI: 10.1093/treephys/tpv011.

Forrester DI, Bauhus J. 2016. A review of processes behind diversity - Productivity relationships in forests. Current Forestry Reports 2: 45-61. DOI: 10.1007/s40725-016-0031-2.

Fox JW. 2005. Interpreting the 'selection effect' of biodiversity on ecosystem function. Ecological Letters 8: 846-856. DOI: 10.1111/j.1461-0248.2005.00795.x.

Geßler A, Keitel C, Kreuzwieser J, Matyssek R, Seiler W, Rennenberg H. 2007. Potential risks for European beech (Fagus sylvatica L.) in a changing climate. Trees 21: 1-11. DOI: 10.1007/s00468006-0107-x.

Hampe A, Petit RJ. 2005. Conserving biodiversity under climate change: the rear edge matters. Ecology Letters 8: 461-467. DOI: 10.1111/j.1461-0248.2005.00739.x.

Huang JG, Bergeron Y, Denneler B, Berninger F, Tardif J. 2007. Response of forest trees to increased atmospheric $\mathrm{CO}_{2}$. Critical Reviews in Plant Sciences 26: 265-283. DOI: 10.1080/07352680701626978.

IPCC. 2013. Summary for Policymakers. In: Stocker TF, Qin D, Plattner G-K, Tignor M, Allen SK, Boschung J, Nauels A, Xia Y, Bex V, Midgley PM (eds.). Climate Change 2013: The Physical Science Basis Contribution of Working Group I to the Fifth Assessment Report of the Intergovernmental Panel on Climate Change. Cambridge University Press: New York. DOI: 10.1017/CBO9781107415324.004.

Jactel H, Nicoll BC, Branco M, González-Olabarría JR, Grodzki W, et al. 2009. The influences of forest stand management on biotic and abiotic risks of damage. Annals of Forest Science 66: 701. DOI: $10.1051 /$ forest/2009054.

Kelty, M.J., Cameron, I.R., 1995. Plot designs for the analysis of species interactions in mixed stands. Commonwealth Forestry Reviews 74: 322-332.

Kimmins JP, Mailly D, Seely B. 1999. Modelling forest ecosystem net primary production: the hybrid simulation approach used in FORECAST. Ecological Modelling 122: 195-224. DOI: 10.1016/S0304-3800(99)00138-6. 
Kimmins JP, Blanco JA, Seely B, Welham C, Scoullar K. 2008. Complexity in modelling forest ecosystems: How much is enough? Forest Ecology and Management 256: 1646-1658. DOI: 10.1016/j.foreco.2008.03.011.

Körner C. 2000. Biosphere responses to $\mathrm{CO}_{2}$ enrichment. Ecological Applications 10: 1590-1619. DOI: 10.1890/1051-0761(2000)010[1590:BRTCE]2.0.CO;2.

Lo YH, Blanco JA, Welham C, Wang M. 2015. Maintaining Ecosystem Function by Restoring Forest Biodiversity: Reviewing Decision-Support Tools that link Biology, Hydrology and Geochemistry. In: Lo Y.H., Blanco J.A., Roy S. (Eds.): Biodiversity in Ecosystems: Linking structure and function. InTech: Rijeka. Pp. 143-167. ISBN 978-953-51-2028-5.

Lodhiyal LS, Singh RP, Singh SP. 1995. Structure and function of an age series of poplar plantations in Central Himalaya. II. Nutrient dynamics. Annals of Botany 76: 201-210. DOI: 10.1006/anbo.1995.1088.

Loreau M, Hector A. 2001. Partitioning selection and complementarity in biodiversity experiments. Nature 412: 72-76. DOI: 10.1038/35083573.

Loreau M, Naeem S, Inchausti P, Bengstsonn J, Grime JP, Hector A, Hooper DU, Huston MA, Raffaelli D, Schmid B, Tilman D, Wardle DA. 2001. Biodiversity and ecosystem functioning: current knowledge and future challenges. Science 294: 804-808. DOI: 10.1126/science.1064088.

Meinshausen M, Smith SJ, Calvin KV, Daniel JS, Kainuma JF, Lamarque M, Matsumoto K, Montzka SA, Raper SCB, Riahi K, Thomsom A, Velders GJM, van Vuuren DPP. 2011. The RCP greenhouse gas concentrations and their extension from 1765 to 2300. Climate Change 109: 213-241. DOI: 10.1007/s10584-011-0156-z.

Messier C, Puettmann KJ, Coates KD. (Eds.), 2013. Managing Forests as Complex Adaptive Systems: Building Resilience to the Challenge of Global Change. Routledge Chapman \& Hall: New York. ISBN: 978-1138779693.

Neumann RB, Cardon ZG. 2012. The magnitude of hydraulic redistribution by plant roots: a review and synthesis of empirical and modeling studies. New Phytologist 194:337-352. DOI: 10.1111/j.14698137.2012.04088.x

Papadakis, J. 1970. Climates of the world, their classification, similitudes, differences, and geographic distribution. Self-edited, Buenos Aires, 47 p.

Penman J, Gytarsky M, Hiraishi T, Krug T, Kruger D. et al. 2003. Good Practice Guidance for Land Use, Land-use Change and Forestry; IPCC National Greenhouse Gas Inventories Programme and Institute for Global Environmental Strategies: Kanagawa, Japan.

Peñuelas J, Boada M. 2003. A global change-induced biome shift in the Montseny Mountains (NE Spain). Global Change Biology 9: 131-140. DOI: 10.1046/j.1365-2486.2003.00566.x. 
Pretzsch H, Schütze G, Uhl E. 2012. Resistance of European tree species to drought stress in mixed versus pure forests: evidence of stress release by inter-specific facilitation. Plant Biology 15: 483495. DOI: 10.1111/j.1438-8677.2012.00670.x.

Pretzsch H, Río M, Ammer Ch, Avdagic A, Barbeito I, Bielak K, Brazaitis G, Coll L, Dirnberger G, Drössler L, Fabrika M, Forrester DI, Heym M, Hurt V, Kurylyak VML, Lombardi F, Mohren F, Motta R, den Ouden J, Pach M, Ponette Q, Schütze G, Schweig J, Skrzyszewski J, Sramek V, Sterba H, Stojanovic D, Svoboda M, Vanhellemont M, Verheyen K, Wellhausen K, Zlatanov T, Bravo-Oviedo A. 2015. Growth and yield of mixed versus pure stands of Scots pine (Pinus sylvestris L.) and European beech (Fagus sylvatica L.) along a gradient of productivity through Europe. European Journal of Forest Research 134: 927-947. DOI: 10. 1007/s10342-015-0900-4.

Primicia I, Camarero JJ, Imbert JB, Castillo FJ. 2013. Effects of thinning and canopy type on growth dynamics of Pinus sylvestris: inter-annual variations and intra-annual interactions with microclimate. European Journal of Forest Research 132: 121-135. DOI: 10.1007/s10342-0120662-1.

Primicia I, Imbert JB, Traver MC, Castillo FJ. 2014. Inter-specific competition and management modify the morphology, nutrient content and resorption in Scots pine needles. European Journal of Forest Research 133: 141-151. DOI: 10.1007/s10342-013-0753-7.

Richards AE, Forrester DI, Bauhus J, Scherer-Lorenzen M. 2010. The influence of mixed tree plantations on the nutrition of individual species: a review. Tree Physiology 30: 1192-1208. DOI: 10.1093/treephys/tpq035.

Río M, Schütze G, Pretzsch H. 2014a. Temporal variation of competition and facilitation in mixed species forests in Central Europe. Plant Biology 16: 166-176. DOI: 10.1111/plb.12029.

Río M, Condés S, Pretzsch H. 2014b. Analyzing size-symmetric vs. size-asymmetric and intra- vs. interspecific competition in beech (Fagus sylvatica L.) mixed stands. Forest Ecology and Management 325: 90-98. DOI: 10.1016/j.foreco.2014.03.047.

Running SW, Nemani RR, Hungerford RD. 1987. Extrapolation of synoptic meteorological data in mountainous terrain and its use for simulating forest evapotranspiration and photosynthesis. Canadian Journal of Forest Research 17: 472-483. DOI: 10.1139/x87-081.

Schwendenmann L, Pendall E, Sanchez-Bragado R, Kunert N, Hölscher D. 2015. Tree water uptake in a tropical plantation varying in tree diversity: interspecific differences, seasonal shifts and complementarity. Ecohydrology 8:1-12. DOI: 10.1002/eco.1479.

Seely B, Arp P, Kimmins JP. 1997. A forest hydrology submodel for simulating the effect of management and climate change on stand water stress. In: Amaro A, Tomé M (Eds.). Proceedings of Empirical and Process-based Models for Forest, Tree and Stand Growth Simulation. Oeiras, Portugal, 21-27 September 1997,Edicões Salamandra, Lisboa, pp. 463-477. 
Seely B, Welham C, Scoullar K. 2015. Application of a hybrid forest growth model to evaluate climate change impacts on productivity, nutrient cycling and mortality in a montane forest ecosystem. PLoS ONE 10: e0135034. DOI: 10.1371/journal.pone.0135034.

Simard SW, Beiler KJ, Bingham MA, Deslippe JR, Philip LJ, Teste FP. 2012. Mycorrhizal networks: mechanisms, ecology and modelling. Fungal Biology Reviews 26:39-60. DOI: 10.1016/j.fbr.2012.01.001.

Sinclair TR, Tanner CB, Bennett JM. 1984. Water-use efficiency in crop production. BioScience 34: 3640. DOI: $10.2307 / 1309424$.

Sterba H, Río M, Brunner A, Condés S. 2014. Effect of species proportion definition on the evaluation of growth in pure vs. mixed stands. Forest Systems 23: 547-559. DOI: 10.5424/fs/2014233-06051.

Titus BD, Prescott CE, Maynard DG, Mitchell AK, Bradley RL, Feller MC, Beese WJ, Benton RA, Senyk JP, Hawkins BJ, Koppenaa R. 2006. Post-harvest nitrogen cycling in clearcut and alternative silvicultural systems in a montane forest in coastal British Columbia. The Forestry Chronicle 62: 844-859. DOI: $10.5558 / \mathrm{tfc} 82844-6$.

Wilby RL, Dawson CW. 2013. The Statistical DownScaling Model: insights from one decade of application. International Journal of Climatology 33: 1707-1719. DOI: 10.1002/joc.3544.

Wu CH, Lo YH, Blanco JA, Chang SC. 2015. Resilience assessment of lowland plantations using an ecosystem modeling approach. Sustainability 7: 3801-3822. DOI: 10.3390/su7043801. 


\section{TABLES}

Table 1. Site characteristics (mean \pm standard error) in 2014. Stands descriptors from Puertas (2001) and Iriarte and Puertas (2003).

\begin{tabular}{|c|c|c|c|c|}
\hline Site & \multicolumn{2}{|c|}{ Mediterranean site } & \multicolumn{2}{|c|}{ Subalpine site } \\
\hline Name of the closest town & \multicolumn{2}{|c|}{ Aspurz } & \multicolumn{2}{|c|}{ Garde } \\
\hline Latitude & \multicolumn{2}{|c|}{$42^{\circ} 48^{\prime} 50^{\prime}, \mathrm{N}$} & \multicolumn{2}{|c|}{$42^{\circ} 42^{\prime} 31^{\prime \prime} \mathrm{N}$} \\
\hline Longitude & \multicolumn{2}{|c|}{$52 ’ 30 ’ \mathrm{~W}$} & \multicolumn{2}{|c|}{$1^{\circ} 8^{\prime} 40^{\prime \prime} \mathrm{W}$} \\
\hline Altitude (m.a.s.1.) & \multicolumn{2}{|r|}{625} & \multicolumn{2}{|c|}{1335} \\
\hline F.A.O. soil type & \multicolumn{2}{|c|}{ Haplic Alisol } & \multicolumn{2}{|c|}{ Dystric Cambisol } \\
\hline \multirow[t]{2}{*}{ Climate type (Papadakis, 1970) } & Cold w & Mediterranean & Cold w & ntinental \\
\hline & Pine stands & Beech stands & Pine stands & Beech stands \\
\hline Slope (\%) & 7 & 37 & 40 & 45 \\
\hline Other overstory tree species ${ }^{\mathrm{a}, \mathrm{b}}$ & $\begin{array}{l}\text { Fagus sylvatica } \mathrm{L} . \\
\text { Quercus humilis } \mathrm{L} .\end{array}$ & $\begin{array}{c}\text { Pinus sylvestris } \mathrm{L} . \\
\text { Alnus glutinosa (L.) Gaertn }\end{array}$ & Fagus sylvatica $\mathrm{L}$. & Pinus sylvestris $\mathrm{L}$. \\
\hline Site Index at stand age 80 years (m) & 29 & 21 & 23 & 18 \\
\hline Age (years) & 47 & 72 & 51 & 38 \\
\hline Density $\left(\text { stems ha }{ }^{-1}\right)^{c}$ & $1456 \pm 140$ & $700 \pm 115$ & $2747 \pm 328$ & $783 \pm 118$ \\
\hline Dominant height $(\mathrm{m})^{\mathrm{d}}$ & $20.4 \pm 0.3$ & $17.3 \pm 0.8$ & $17.3 \pm 0.9$ & $13.2 \pm 0.5$ \\
\hline Mean DBH $(\mathrm{cm})^{\mathrm{e}}$ & $18.9 \pm 1.0$ & $14.2 \pm 0.7$ & $14.8 \pm 0.2$ & $9.5 \pm 0.4$ \\
\hline Basal area $\left(\mathrm{m}^{2} \mathrm{ha}^{-1}\right)$ & $41.2 \pm 0.9$ & $13.5 \pm 6.6$ & $47.8 \pm 1.6$ & $15.0 \pm 4.0$ \\
\hline
\end{tabular}

${ }^{a}$ Scots pine plots: eighteen and ten tree species identified in the Mediterranean and the subalpine sites, respectively

${ }^{\mathrm{b}}$ European beech plots: seven and two tree species identified in the Mediterranean and the subalpine sites, respectively

${ }^{\mathrm{c}}$ Trees with a diameter $>7.5 \mathrm{~cm}$ at breast height $(1.30 \mathrm{~m}, \mathrm{DBH})$.

${ }^{\mathrm{d}}$ Measured averaging $(\mathrm{n}=100)$ the height of the thickest dominant trees per hectare.

${ }^{\mathrm{e}}$ Measured by double cross measurement. 
Table 2. Soil chemical and physical properties in the study sites. Parameters in bold are plant-available water related values used to calibrate the hydrological submodel.

\begin{tabular}{|c|c|c|c|c|c|c|c|c|c|}
\hline Site/Horizon & Texture & $\begin{array}{c}\text { Coarse } \\
\text { fragment } \\
\text { content }(\%)\end{array}$ & $\begin{array}{c}\text { Depth }^{\mathrm{a}} \\
(\mathrm{cm})\end{array}$ & $\begin{array}{c}\mathrm{pH} \mathrm{1:2.5} \\
\mathrm{H}_{2} \mathrm{O}\end{array}$ & $\begin{array}{l}\text { Density } \\
\left(\text { g.cm }^{-3}\right)\end{array}$ & $\begin{array}{c}\text { CEC } \\
\left(\mathrm{cmol}^{-} . \mathrm{kg}^{-1}\right)\end{array}$ & $\begin{array}{l}\text { O.M. } \\
(\%)\end{array}$ & $\begin{array}{l}\text { Soil } \\
\text { C/N }\end{array}$ & $\begin{array}{c}\text { Maximum } \\
\text { field capacity } \\
(\%)\end{array}$ \\
\hline \multicolumn{10}{|c|}{ Mediterranean site } \\
\hline Horizon $\mathrm{O}$ & - & $\mathbf{0}$ & 9.7 & - & 0.24 & - & - & 43.1 & 32.0 \\
\hline Horizon A & Sandy loam & 20 & 20.0 & 6.25 & 0.38 & 18.6 & 10.41 & 23.3 & 38.8 \\
\hline Horizon B & Sandy loam & 20 & 50.0 & 5.32 & 1.89 & 6.6 & 1.63 & 20.5 & 38.8 \\
\hline \multicolumn{10}{|l|}{ Subalpine site } \\
\hline Horizon $\mathrm{O}$ & - & $\mathbf{0}$ & 8.8 & - & 0.24 & - & - & 56.5 & 32.0 \\
\hline Horizon A & Loam & 30 & 25.0 & 5.83 & 0.76 & 26.6 & 9.07 & 15.6 & 38.8 \\
\hline Horizon B & Loam & 30 & 60.0 & 5.76 & 1.27 & 18.2 & 2.71 & 9.4 & 38.8 \\
\hline
\end{tabular}


Table 3. Parameter values in the hydrological submodel specific to the simulation of evapotranspiration and water stress for trees and understory vegetation.

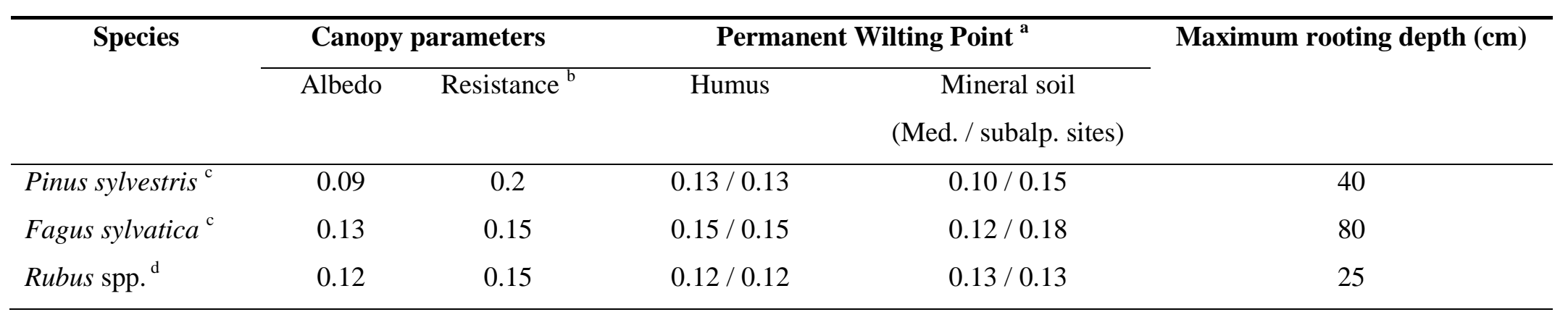

${ }^{\text {a }}$ Relative volumetric moisture content (proportion of total volume) at which soil water uptake is suspended.

${ }^{\mathrm{b}}$ Reference relative canopy resistance to water loss through stomata. Higher values indicate greater resistance

${ }^{\mathrm{c}}$ Tree species.

${ }^{\mathrm{d}}$ Understory species.

Table 4. Percentage of precipitation intercepted by the canopy (mean \pm SE) for stand age 50-150 years. Different superscripts mean statistically significant differences among stands types. Statistical comparison were performed with univariate ANOVA.

\begin{tabular}{lcccccc}
\hline & \multicolumn{3}{c}{ Mediterranean site } & \multicolumn{3}{c}{ Subalpine site } \\
\cline { 2 - 7 } & Historical & $R C P 4.5$ & $R C P 8.5$ & Historical & $R C P 4.5$ & $R C P 8.5$ \\
\hline Pine stands & $15.77 \pm 0.53^{\mathrm{a}}$ & $11.17 \pm 2.45^{\mathrm{a}}$ & $12.45 \pm 2.77^{\mathrm{a}}$ & $5.05 \pm 0.27^{\mathrm{a}}$ & $4.20 \pm 1.14^{\mathrm{a}}$ & $4.87 \pm 1.33^{\mathrm{a}}$ \\
Beech stands & $11.33 \pm 0.43^{\mathrm{b}}$ & $7.96 \pm 1.93^{\mathrm{b}}$ & $8.58 \pm 2.08^{\mathrm{b}}$ & $3.78 \pm 0.23^{\mathrm{b}}$ & $2.74 \pm 0.90^{\mathrm{b}}$ & $3.07 \pm 0.99^{\mathrm{b}}$ \\
Mixed stands & $15.99 \pm 0.54^{\mathrm{a}}$ & $11.19 \pm 2.35^{\mathrm{a}}$ & $11.98 \pm 2.42^{\mathrm{a}}$ & $4.64 \pm 0.26^{\mathrm{a}}$ & $3.88 \pm 1.11^{\mathrm{a}}$ & $4.63 \pm 1.36^{\mathrm{a}}$ \\
\hline
\end{tabular}




\section{Figure legends}

Figure 1. Natural European distribution of Pinus sylvestris, Fagus sylvatica (EUFORGEN, 2009) and the common area between both species. The left upper inset shows the location of experimental plots (circles): Mediterranean site (Aspurz) and subalpine site (Garde); weather stations providing historical climate (triangles) and weather stations averaged for climate change scenarios projection (stars). Lower pictures show images from experimental pine (upper) and beech (lower) stands.

Figure 2. Climatic diagrams for the study sites for the period 1975-2004 for the Mediterranean site (Aspurz) and the subalpine site (Garde). $y$ represents number of years considered; $T$ : mean annual temperature $\left({ }^{\circ} \mathrm{C}\right)$; P: mean annual amount of precipitation $(\mathrm{mm})$. Oblique striped area shows months with an absolute minimum temperature below $0{ }^{\circ} \mathrm{C}$.

Figure 3. (A) Stand complementarity effects on stemwood yield calculated as in Eq. 3. (B) Species complementarity effects on stemwood yield at age 150 calculated following Eq. 2. The horizontal axis sums up resources gradients that occur between the two sites with different elevation (Mediterranean left side, subalpine right side).

Figure 4. Stand level descriptors in monospecific Pinus sylvestris and Fagus sylvatica stands and pine/beech mixtures simulated under historical climate scenario. (A) Total stand growth per year $\left(\mathrm{Mg} \mathrm{ha}^{-1}\right.$ year $\left.^{-1}\right)$. (B) Soil nitrogen net balance $\left(\mathrm{kg} \mathrm{ha}^{-1}\right)$ calculated as the difference between nitrogen released from litter and humus and leaching losses. (C) Actual stand canopy transpiration ( $\left.\mathrm{mm} \mathrm{ha}^{-1}\right)$. (D) Ecosystem-level nitrogen use efficiency $\left(\mathrm{Mg} \mathrm{kg}^{-1} \mathrm{~N}\right)$.

Figure 5. Differences between Pinus sylvestris output parameters in monospecific stands and mixed stands. Positive values indicate higher values in monospecific stands relative to mixtures. Thick lines represent average and color areas represent 95\% and 5\% percentiles; the purple area represents the overlap between the moderate (blue) and severe (red) climate change scenarios. (A) Amount of nitrogen accumulated in foliage biomass per tree $\left(\mathrm{kg} \mathrm{N} \mathrm{stem}^{-1}\right)$; (B) actual water transpired per tree $\left(\mathrm{mm} \mathrm{stem}^{-1}\right)$; (C) transpiration deficit index (TDI) as a measure of water stress experienced by the species; (D) and water-use efficiency (WUE; $\mathrm{Mg} \mathrm{mm}^{-1}$ ).

Figure 6. Differences between Fagus sylvatica parameters in monospecific stands and mixed stands. Positive values indicate higher values in monospecific stands relative to mixtures. Thick lines represent average and color areas represent 95\% and 5\% percentiles; the purple area represents the overlap between the moderate (blue) and severe (red) climate change scenarios. (A) Amount of nitrogen accumulated in foliage biomass per tree $\left(\mathrm{kg} \mathrm{N} \mathrm{stem}^{-1}\right)$; (B) actual water transpired per tree $\left(\mathrm{mm} \mathrm{stem}^{-1}\right)$; (C) transpiration deficit index (TDI) as a measure of water stress experienced by the species; (D) and water-use efficiency (WUE; $\mathrm{Mg} \mathrm{mm}^{-1}$ ). 
Figure 7. Stand level descriptors in Pinus sylvestris and Fagus sylvatica mixtures simulated in FORECAST Climate under different climate scenarios: historical, moderate (RCP 4.5) and severe climate change (RCP 8.5). Thick lines represent average and color areas represent $95 \%$ and $5 \%$ percentiles; the purple area represents the overlap between the moderate and severe climate change scenarios. (A) Total stand growth per year $\left(\mathrm{Mg} \mathrm{ha}^{-1} \mathrm{year}^{-1}\right)$. (B) Soil nitrogen net balance $\left(\mathrm{kg} \mathrm{N} \mathrm{ha}^{-1}\right)$ calculated as the difference between nitrogen released from litter and humus and leaching losses. (C) Total actual stand canopy transpiration ( $\left.\mathrm{mm} \mathrm{ha}^{-1}\right)$ determined in the forest hydrology model ForWaDy. (D) Impact of climate on decomposition processes in the soil layers or Climate Decomposition Factor (CDF; dimensionless). 


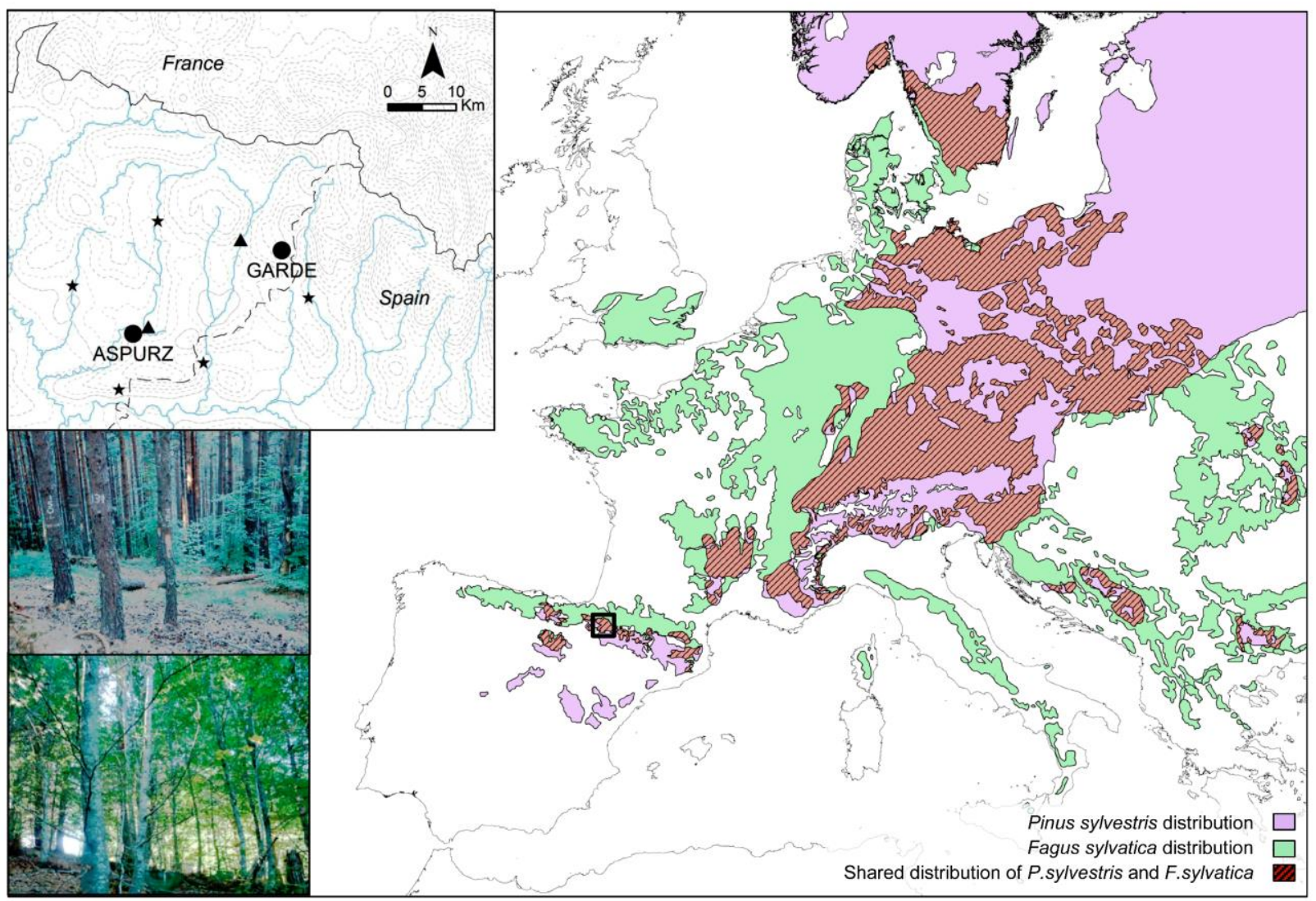

Figure 1. 

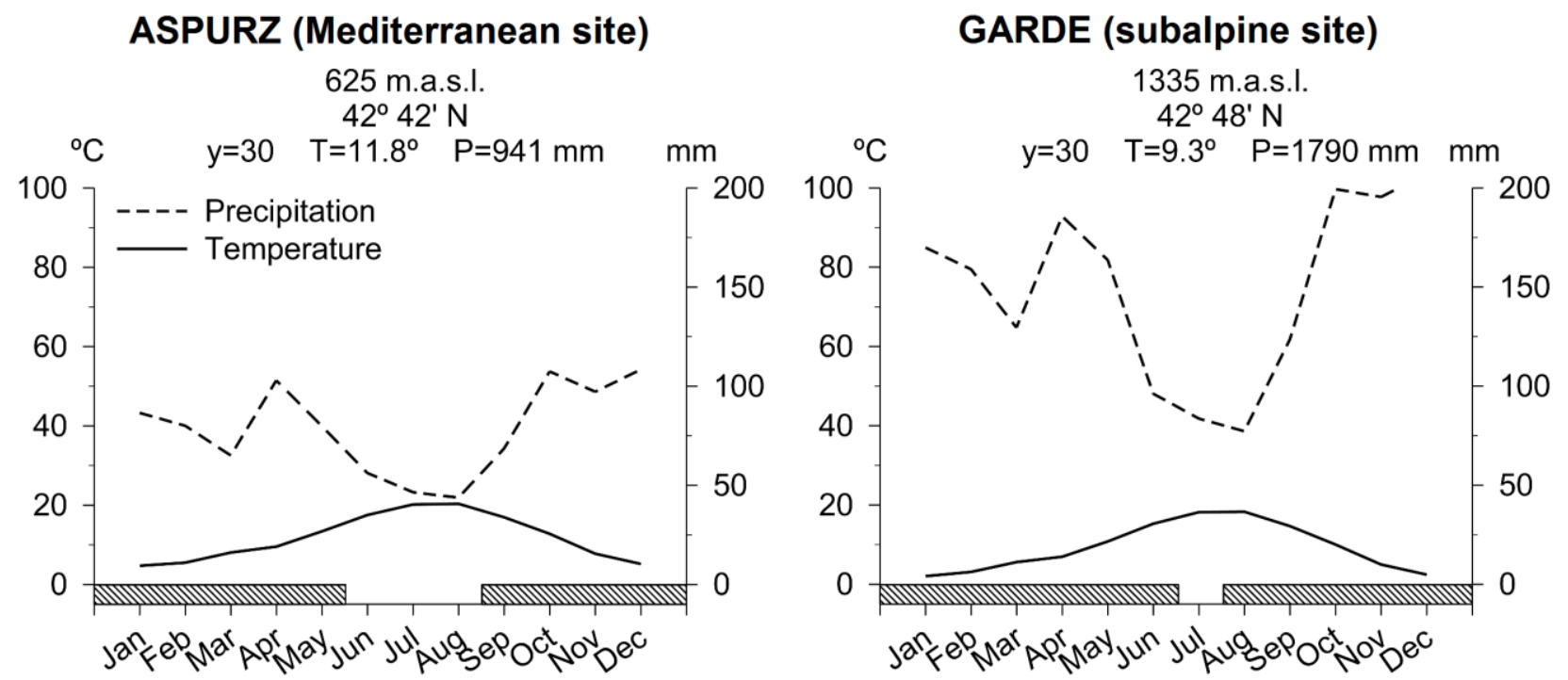

Figure 2. 

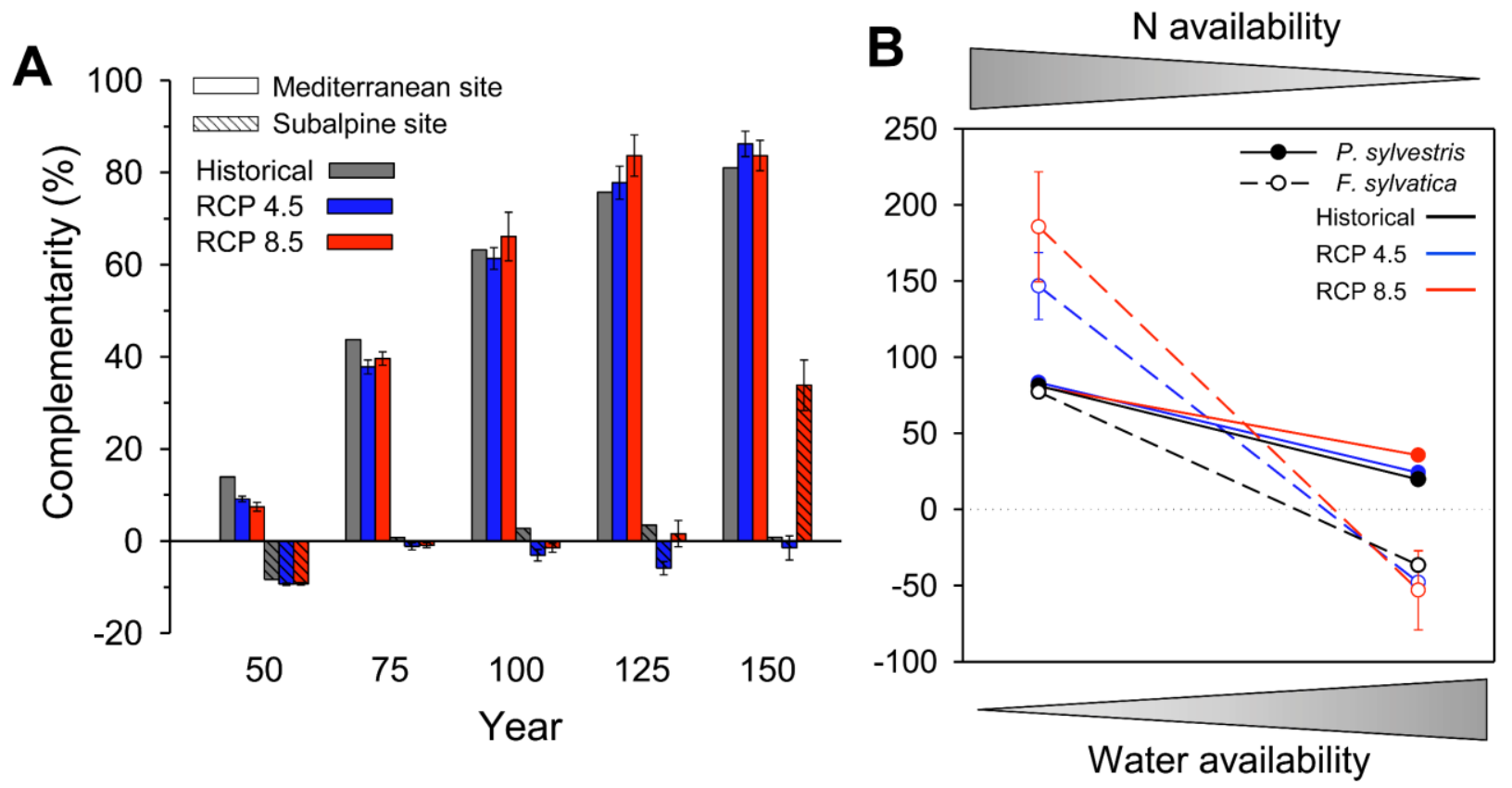

Figure 3. 
Mixed stands

MEDITERRANEAN SITE

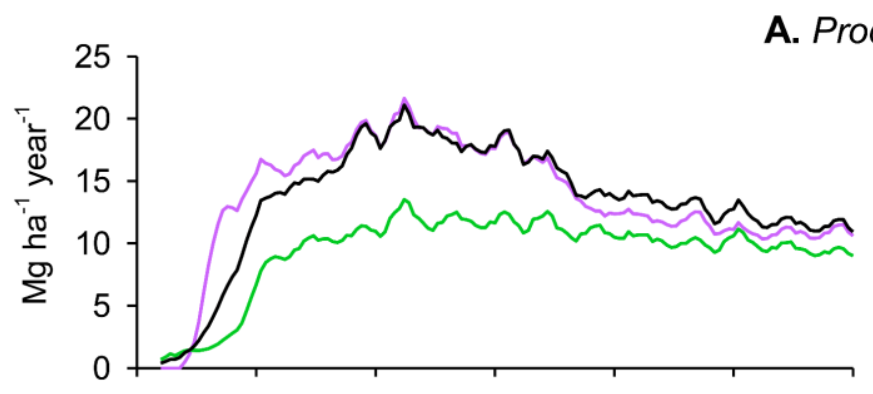

SUBALPINE SITE

A. Productivity

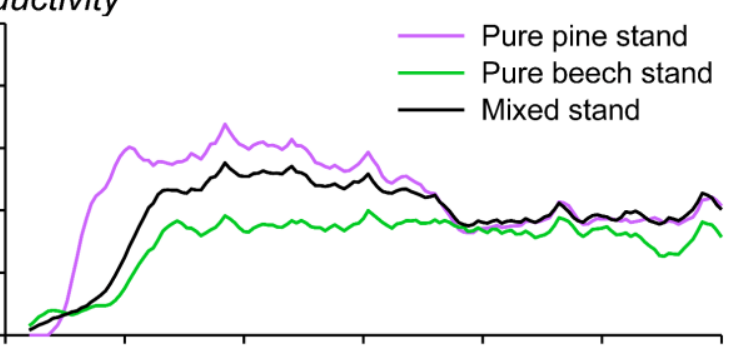

B. Soil $N$ net balance
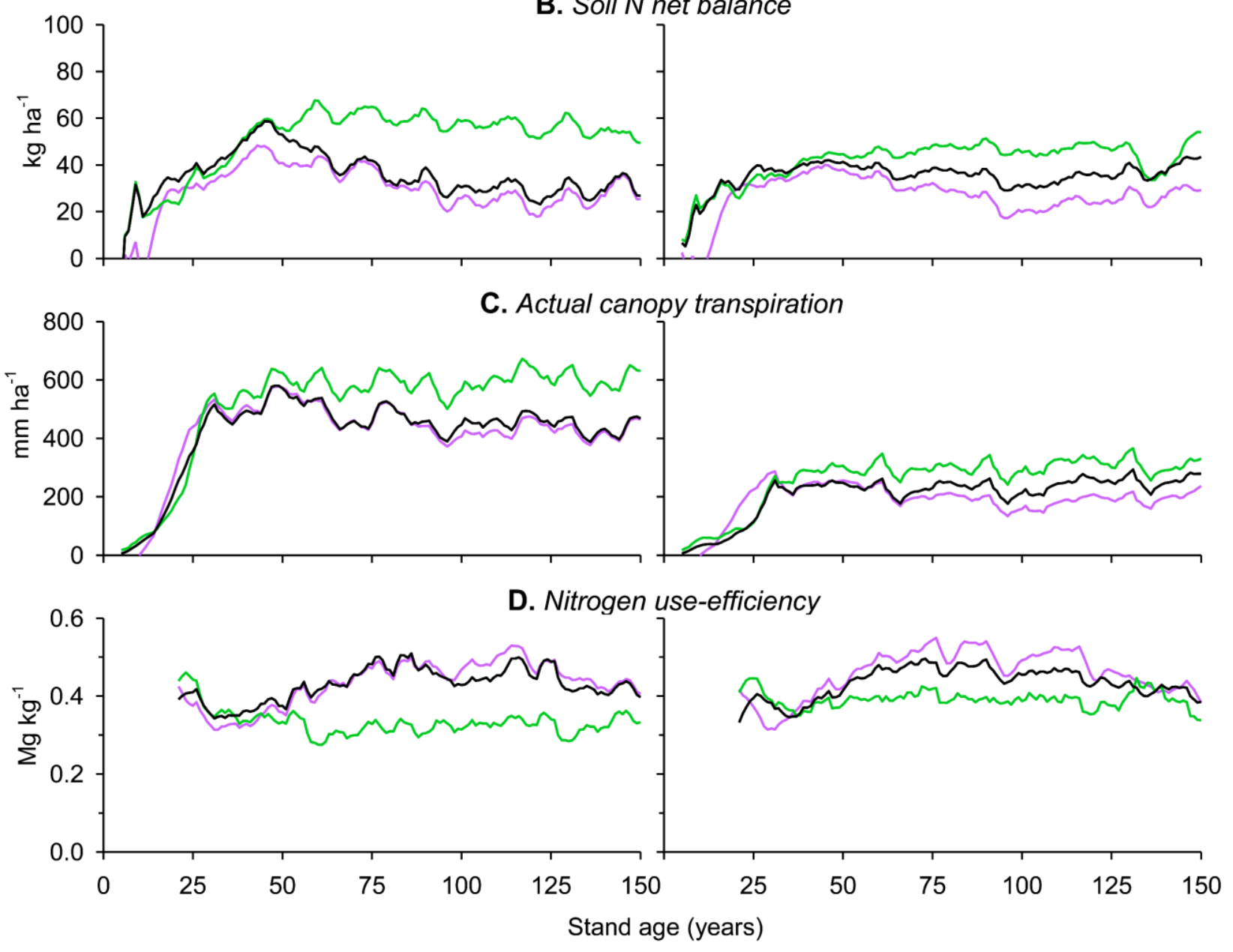

Figure 4. 


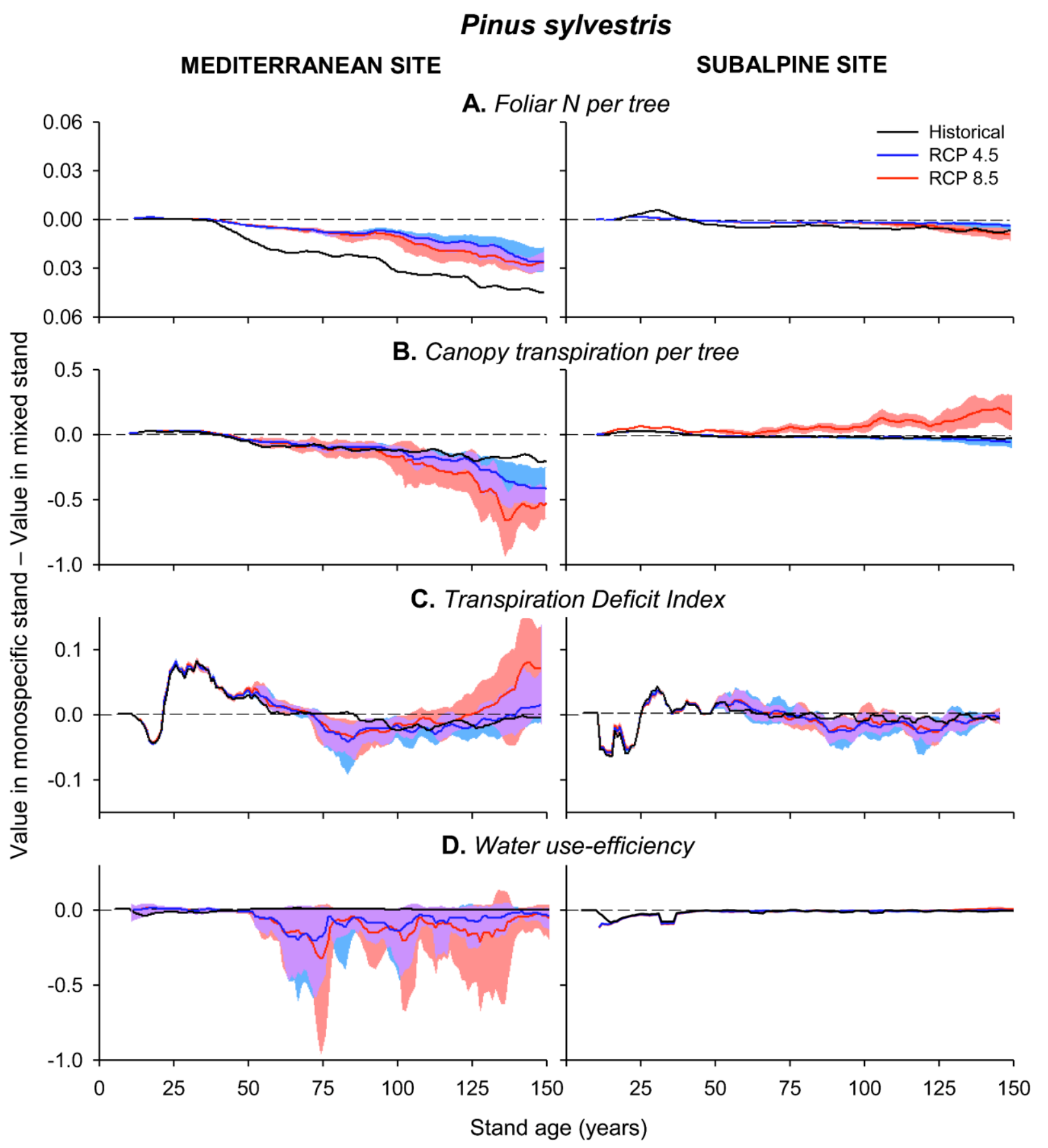

Figure 5. 
Fagus sylvatica

MEDITERRANEAN SITE

SUBALPINE SITE
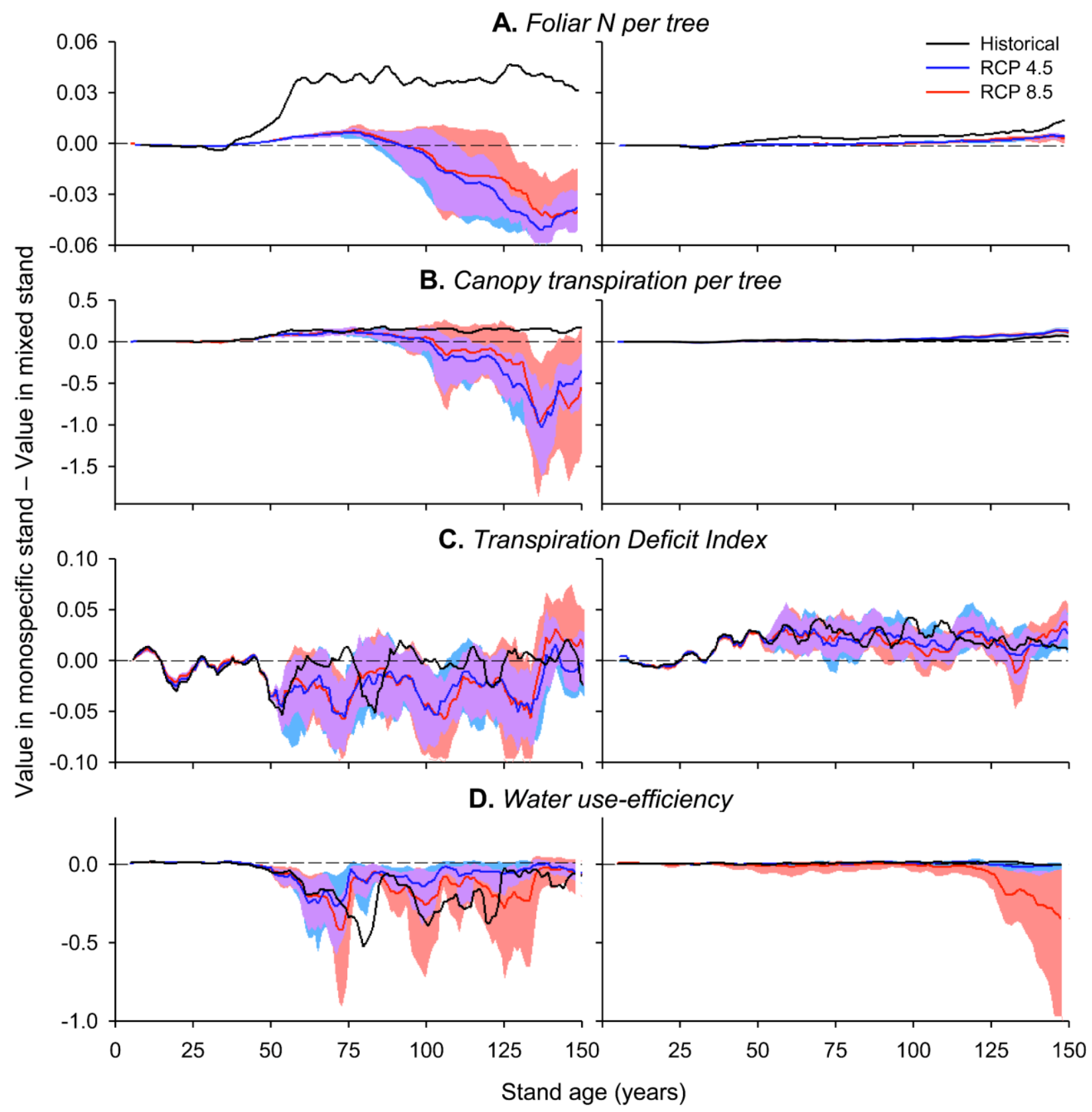

Figure 6. 

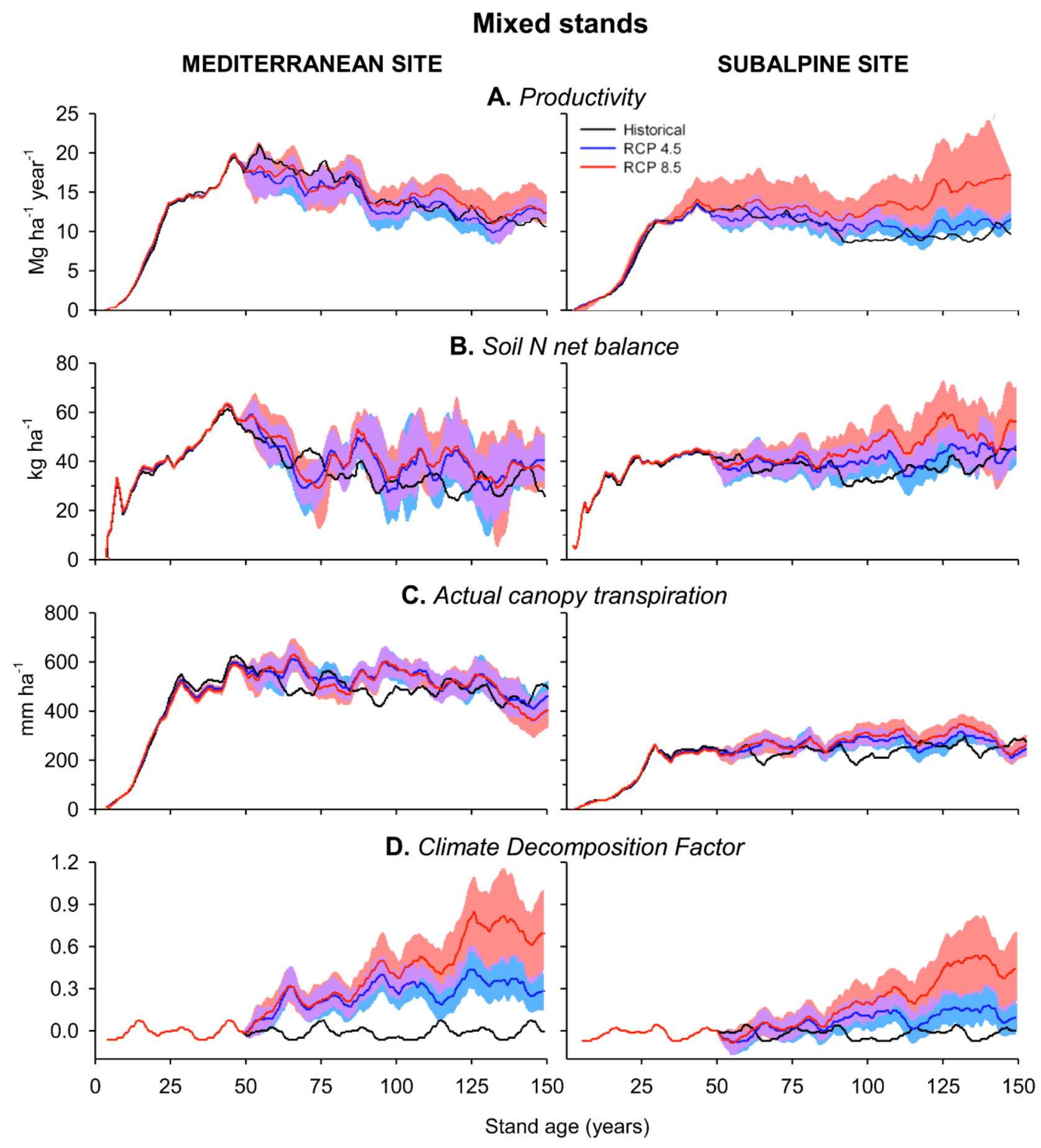

Figure 7. 